DOI : https://doi.org/10.24843/JFU.2020.v09.i03.p07

pISSN: 2301-7716; eISSN: 2622-4607

Jurnal Farmasi Udayana, Spesial Issue Desember 2020, 187-194

\title{
Potensi Sediaan Kapsul Ekstrak Etanol Kulit Pisang Klutuk Sebagai Antidiabetes
}

\author{
Nofianti $\mathbf{T}^{\mathbf{1}}$, Threemadunintyas $\mathbf{A}^{\mathbf{1}}$, Nurdianti $\mathbf{L}^{\mathbf{1}}$, Muhtadi $\mathbf{A}^{\mathbf{2}}$, Fidrianny $\mathbf{I}^{\mathbf{3}}$ \\ ${ }^{1}$ STIKes Bakti Tunas Husada, Jalan Cilolohan No 36, Tasikmalaya, Indonesia, 46115 \\ ${ }^{2}$ Universitas Padjdjaran, Jalan Raya Bandung Sumedang KM 21, Jatinangor, Indonesia, 45363 \\ ${ }^{3}$ Instutut Teknologi Bandung, Jalan Ganesha No 10, Bandung, Indonesia, 40132 \\ *Corresponding author e-mail: titanofianti.wamsu@gmail.com
}

Riwayat artikel: Dikirim: 15/10/2020; Diterima: 26/10/2020, Diterbitkan: 15/12/2020

\begin{abstract}
Diabetes mellitus (DM) is a metabolic disease characterized by high blood glucose levels. Klutuk banana peels contain secondary metabolites such as flavonoids, polyphenols, and saponins which can reduce blood glucose levels. The aim of this study was to determine the activity and good formula of the capsules of the ethanol extract of the klutuk banana peel (Musa balbisiana Colla) as antidiabetic in male alloxan-induced mice. Alloxan used at a dose of $170 \mathrm{mg} / \mathrm{kg} \mathrm{BW}$. Mice were divided into 5 groups consisting of negative control groups (CMC Na 0.5\%), positive control groups (metformin $1.3 \mathrm{mg} / 20 \mathrm{~g} \mathrm{BW}$ mice), F1 group (3.5 mg/20 g BW mice with $2 \%$ Sodium Starch Glycolate -SSG), group F2 (3.5 mg/20 g BW of mice with 4\% SSG), and group F3 (3.5 mg/20 g BW of mice with $8 \% \mathrm{SSG}$ ). The analysis showed that there was no significant difference between the positive control group and the F2 group. The percentage decrease in blood glucose levels obtained is $65.05 \%$. The results of the evaluation of the preparations indicate that all three capsule preparation formulas meet the requirements. The results of this study indicate that the capsule preparation with formula 2 has an activity to lower blood glucose levels better than formulas 1 and 3 in alloxan-induced mice.
\end{abstract}

Keywords: Diabetes mellitus, klutuk banana peel, Musa balbisiana, capsule preparation.

\begin{abstract}
ABSTRAK
Diabetes melitus (DM) adalah suatu penyakit metabolik yang ditandai dengan tingginya kadar glukosa darah. Kulit pisang klutuk mengandung metabolit sekunder seperti flavonoid, polifenol, dan saponin yang dapat menurunkan kadar glukosa darah. Penelitian ini bertujuan untuk mengetahui aktivitas dan formula yang baik sediaan kapsul ekstrak etanol kulit pisang klutuk (Musa balbisiana Colla) sebagai antidiabetes pada mencit jantan yang diinduksi aloksan. Aloksan yang digunakan dengan dosis $170 \mathrm{mg} / \mathrm{kg}$ BB. Mencit dibagi menjadi 5 kelompok yang terdiri dari kelompok kontrol negatif (CMC Na 0,5\%), kelompok kontrol positif (metformin $1,3 \mathrm{mg} / 20 \mathrm{~g}$ BB mencit), kelompok F1 (3,5 mg/20 g BB mencit dengan $2 \%$ Sodium Starch Glycolate -SSG), kelompok F2 (3,5 mg/ $20 \mathrm{~g}$ BB mencit dengan $4 \%$ SSG), dan kelompok F3 (3,5 mg/ $20 \mathrm{~g}$ BB mencit dengan $8 \%$ SSG). Hasil analisis menunjukkan tidak ada perbedaan bermakna antara kelompok kontrol positif dan kelompok F2. Persentase penurunan kadar glukosa darah yang diperoleh yaitu 65,05\%. Hasil evaluasi sediaan menunjukkan bahwa ketiga formula sediaan kapsul memenuhi persyaratan. Hasil penelitian ini menunjukkan bahwa sediaan kapsul dengan formula 2 mempunyai aktivitas menurunkan kadar glukosa darah yang lebih baik daripada formula 1 dan 3 pada mencit yang diinduksi aloksan.
\end{abstract}

Kata kunci: Diabetes melitus, kulit pisang klutuk, Musa balbisiana, sediaan kapsul. 
DOI : https://doi.org/10.24843/JFU.2020.v09.i03.p07

pISSN: 2301-7716; eISSN: 2622-4607

Jurnal Farmasi Udayana, Spesial Issue Desember 2020, 187-194

\section{PENDAHULUAN}

Diabetes melitus (DM) adalah suatu penyakit metabolik yang ditandai dengan gejala tingginya kadar glukosa darah (hiperglikemia) sebagai akibat gangguan sekresi insulin (Adnyana, 2016). Menurut International Diabetes Federation (IDF) atlas tahun 2018 mengenai perkiraan global prevalensi diabetes menunjukkan bahwa tahun 2017 terdapat 451 juta penderita diabetes di seluruh dunia dan diperkirakan meningkat menjadi 693 juta pada tahun 2045.

Indonesia memiliki kurang lebih 200 jenis pisang yang tersebar di seluruh penjuru pulau. Banyak masyarakat tidak tahu manfaat buah pisang secara farmakologis karena minimnya sosialisasi kepada masyarakat terkait manfaat pisang (Arifki et al., 2018). Salah satu jenis pisang yang memiliki potensi sebagai antidiabetes yaitu pisang klutuk (Musa balbisiana Colla) yang termasuk famili Musaceae. Berdasarkan penelitian yang dilakukan Nurhayati (2019), menunjukkan hasil bahwa ekstrak etanol kulit pisang klutuk mempunyai aktivitas sebagai antidiabetes. Hasil skrining fitokimia pada kulit pisang klutuk ditemukan adanya kandungan senyawa alkaloid, flavonoid, polifenol, saponin, tanin, monoterpenoid, seskuiterpenoid dan triterpenoid.

Penggunaan obat tradisional oleh masyarakat Indonesia semakin meningkat karena harganya yang lebih murah dan memiliki efek samping yang minimal. Namun, kekurangan ekstrak atau bahan alam sebagai pengobatan adalah cenderung memiliki rasa yang tidak enak dan bau yang khas. Oleh karena itu, untuk menutupi kekurangan tersebut sediaan dibuat dalam bentuk kapsul.

Berdasarkan uraian tersebut maka dilakukan penelitian tentang aktivitas antidiabetes sediaan kapsul ekstrak etanol kulit pisang klutuk (Musa balbisiana Colla) pada mencit jantan yang diinduksi aloksan.

\section{BAHAN DAN METODE}

\subsection{Bahan dan Alat}

\subsubsection{Alat}

Alat-alat yang digunakan dalam penelitian ini adalah kandang pemeliharaan tikus, timbangan analitik (excellent), spuit injeksi $1,0 \mathrm{~mL}$, sonde oral, glukometer, blender, alat-alat gelas, alat bedah, alat refluks, rotary evaporator (R-300 BUCHIBUCHI), water bath (memmert WNB14RING).

\subsubsection{Bahan}

Bahan-bahan yang digunakan dalam penelitian ini adalah kulit pisang klutuk (Musa balbisiana Colla), metformin, aloksan, etanol 96\%, CMC Na, aquadest, water for injection, serbuk Zn, larutan alkohol asam klorida (1:1), amil alkohol, $\mathrm{HCl} 2 \mathrm{~N}$, pereaksi Mayer, pereaksi Dragendorff, pereaksi besi (III) korida, gelatin 1\%, anisaldehide-asam sulfat, Liebermann Burchad, $\mathrm{NaOH}$, stik glukosa, talk, sodium starch glycolate, avicel 101.

\subsection{Metode}

\subsubsection{Pembuatan Ekstrak Etanol Kulit Pisang} Klutuk

Ekstraksi kulit pisang klutuk (Musa balbisiana Colla) dilakukan dengan metode refluks, simplisia ditimbang sebanyak 200 gram, kemudian dimasukkan ke dalam alat refluks dan ditambahkan etanol $96 \%$ sampai serbuk simplisia terendam, setelah itu alat refluks disiapkan. Refluks dilakukan sebanyak 3 kali siklus. Ekstrak etanol disaring kemudian dilakukan evaporasi pada suhu $60-70^{\circ} \mathrm{C}$ dan didapat ekstrak pekat, kemudian diuapkan dengan menggunakan waterbath hingga diperoleh ekstrak kental. Selanjutnya dilakukan 
DOI : https://doi.org/10.24843/JFU.2020.v09.i03.p07

pISSN: 2301-7716; eISSN: 2622-4607

Jurnal Farmasi Udayana, Spesial Issue Desember 2020, 187-194

skrining fitokimia untuk mengetahui senyawa metabolit sekunder.

\subsubsection{Pembuatan Sediaan Kapsul Ekstrak Kulit} Pisang Klutuk

Pembuatan sediaan kapsul ekstrak kulit pisang klutuk dilakukan dengan metode granulasi basah. Ekstrak dicampurkan dengan avicel 101 sampai terbentuk massa basah yang sesuai untuk dibuat granul. Massa basah kemudian diayak menggunakan ayakan mesh no 10. Granul basah kemudian dikeringkan dengan menggunakan oven pada suhu $60^{\circ} \mathrm{C}$. Granul kering dicampur dengan talk 3\% dan SSG kemudian aduk. Granul yang telah jadi dimasukkan ke dalam cangkang kapsul (Jyothi et al., 2017).

Tabel 1. Formula Sediaan

\begin{tabular}{ccccc}
\hline \multirow{2}{*}{ Bahan } & Fungsi & Kormula & Formula & Formula \\
& & $\mathbf{1}$ & $\mathbf{2}$ & $\mathbf{3}$ \\
\hline Ekstrak Kulit Pisang Klutuk & Zat aktif & $678 \mathrm{mg}$ & $678 \mathrm{mg}$ & $678 \mathrm{mg}$ \\
Talk & Pelicin, pengatur aliran & $3 \%$ & $3 \%$ & $3 \%$ \\
Sodium Starch Glycolate & Disintegran & $2 \%$ & $4 \%$ & $8 \%$ \\
Avicel 101 & Pengikat, pengisi & Ad 1 g & Ad 1 g & Ad 1 g \\
\hline
\end{tabular}

\section{Evaluasi Sediaan}

Evaluasi sediaan dilakukan pada sediaan granul dan kapsul. Evaluasi sediaan granul yang dilakukan yaitu uji laju alir dan sudut istirahat. Evaluasi sediaan kapsul yang dilakukan uji keseragaman bobot.

\section{Pengelompokan Hewan Uji}

Sebanyak 25 ekor mencit jantan galur swiss webster dibagi menjadi 5 kelompok uji sebanyak 5 ekor :

1. Kelompok kontrol negatif, diberikan larutan $\mathrm{Na}$ CMC 0,5\%

2. Kelompok kontrol positif, diberikan metformin

3. Kelompok F1, diberikan sediaan ekstrak etanol kulit pisang klutuk formula 1

4. Kelompok F2, diberikan sediaan ekstrak etanol kulit pisang klutuk formula 2

5. Kelompok F3, diberikan sediaan ekstrak etanol kulit pisang klutuk formula 3

Uji Aktivitas Antidiabetes
Seluruh hewan uji diambil darahnya yang sebelumnya dipuasakan dulu selama 12-15 jam dan diukur kadar glukosa darah awal. Selanjutnya diinduksi secara intraperitonial dengan aloksan pada dosis $170 \mathrm{mg} / \mathrm{kg}$ BB. Dosis aloksan yang digunakan induksi diabetes pada mencit yaitu sebesar 3,4 mg/20 gram BB mencit. (Ighodaro et al., 2018).

Tiga hari setelah diinduksi aloksan kadar glukosa darah mencit diukur kembali, jika terjadi kenaikan kadar glukosa darah mencit menjadi \pm $200 \mathrm{mg} / \mathrm{dL}$ maka mencit dianggap sudah diabetes. Selanjutnya pengambilan darah pada hari ke 7 dan hari ke 14 setelah pemberian sediaan uji, kadar glukosa darah mencit diukur kembali untuk dibandingkan dengan kadar glukosa darah setelah diinduksi aloksan pada hari ke 3. Pengukuran kadar glukosa darah dilakukan dengan menggunakan glukometer (Liem et al., 2015).

\section{Analisis Data}


DOI : https://doi.org/10.24843/JFU.2020.v09.i03.p07

pISSN: 2301-7716; eISSN: 2622-4607

Jurnal Farmasi Udayana, Spesial Issue Desember 2020, 187-194

Data hasil pengukuran kadar glukosa darah yang diperoleh dianalisis dengan menggunakan program SPSS. Pengujian yang dilakukan yaitu uji normalitas, uji homogenitas, uji ANOVA untuk mengetahui adanya perbedaan dari tiap kelompok, dan dilakukan uji lanjutan yaitu uji LSD untuk mengetahui perbedaan kelompok uji yang memberikan perbedaan bermakna (Priyatno, 2012).

\section{HASIL}

Berdasarkan hasil penelitian rendemen ekstrak yang didapatkan yaitu 5,14\%. Rendemen yang dihasilkan tersebut diperoleh dari simplisia sebanyak 1050 gram dan menghasilkan ekstrak sebanyak 53,97 gram. Hasil skrining fitokimia simplisia kulit pisang klutuk mengandung senyawa golongan flavonoid, tanin, polifenol, saponin, kuinon, monoterpenoid dan seskuiterpenoid. Sedangkan pada ekstrak etanol kulit pisang klutuk mengandung senyawa golongan flavonoid, polifenol, saponin, kuinon, monoterpenoid dan seskuiterpenoid, namun tidak terdeteksi tanin. Hal tersebut dapat disebabkan karena skrining fitokimia yang dilakukan dapat saja tidak mampu mendeteksi kandungan bahan kimia yang jumlahnya hanya sedikit setelah melalui proses ekstraksi (Purwati et al., 2017).

Tabel 2. Hasil Skrining Fitokimia

\begin{tabular}{clcc}
\hline No. & \multicolumn{1}{c}{ Golongan Senyawa } & Simplisia & Ekstrak \\
\hline 1. & Flavonoid & + & + \\
2. & Alkaloid & - & - \\
3. & Tanin & + & - \\
4. & Polifenol & + & + \\
5. & Saponin & + & + \\
6. & Monoterpenoid dan Seskuiterpenoid & + & + \\
7. & Steroid dan Triterpenoid & - & - \\
8. & Kuinon & + & + \\
\hline
\end{tabular}

Keterangan :

(+) Terdeteksi

(-) Tidak Terdeteksi

Evaluasi sediaan granul yang pertama yaitu uji laju alir. Pengujian laju alir dilakukan untuk mengetahui kecepatan laju alir dari sediaan yang dibuat. Hasil menunjukkan laju alir yang diperoleh baik yaitu $\leq 10$ detik. Hasil tersebut menunjukkan bahwa granul yang diperoleh mengalir dengan baik. Selanjutnya uji sudut istirahat dilakukan untuk mengetahui sifat aliran dari sediaan, hasil menunjukkan bahwa nilai sudut istirahat yang diperoleh memenuhi persyaratan karena kurang dari $38^{\circ}$ (Voight, 1989).

Tabel 3. Hasil Rata-rata Evaluasi Sediaan Granul

\begin{tabular}{ccc}
\hline Formula & Laju Alir (g/detik) & Sudut Istirahat $\left(^{\mathbf{o}}\right)$ \\
\hline 1 & $7,88 \pm 0,52$ & $16,79 \pm 1,97$ \\
2 & $8,52 \pm 0,04$ & $12,91 \pm 1,15$ \\
3 & $8,48 \pm 0,11$ & $13,51 \pm 2,59$ \\
\hline
\end{tabular}


DOI : https://doi.org/10.24843/JFU.2020.v09.i03.p07

pISSN: 2301-7716; eISSN: 2622-4607

Jurnal Farmasi Udayana, Spesial Issue Desember 2020, 187-194

Evaluasi sediaan kapsul yang dilakukan yaitu uji keseragaman bobot untuk mengetahui pada setiap formula yang dibuat menghasilkan kapsul dengan bobot yang sama atau tidak. Keseragaman bobot juga akan berpengaruh terhadap keamanan terapi dari sediaan yang dibuat (Ainurofiq dan Azizah 2016). Hasil uji keseragaman bobot ketiga formula memenuhi standar yang telah ditetapkan yaitu keseragaman bobot yang diperoleh $<7,5 \%$ (Departemen Kesehatan RI, 1979).

Tabel 4. Hasil Rata-rata Evaluasi Sediaan Kapsul

\begin{tabular}{ccc}
\hline \multirow{2}{*}{ Formula } & \multicolumn{2}{c}{ Keseragaman Bobot } \\
\cline { 2 - 3 } & Bobot Rata-rata $(\mathbf{m g}) \pm$ SD & Penyimpangan Rata-rata (\%) \pm SD \\
\hline 1 & $970 \pm 0,05$ & $4,35 \pm 1,62$ \\
2 & $980 \pm 0,04$ & $3,43 \pm 2,81$ \\
3 & $950 \pm 0,06$ & $5,78 \pm 1,77$ \\
\hline
\end{tabular}

Hasil nilai rata-rata kadar glukosa darah pada kelompok kontrol negatif tidak terjadi penurunan tetapi terjadi peningkatan pada hari ke 7 adalah 508,60 mg/dL menjadi 561,80 mg/dL pada hari ke 14. Hal ini disebabkan karena CMC-Na tidak mempunyai khasiat sebagai antidiabetes. Pada kelompok kontrol positif nilai rata-rata kadar glukosa darah hari ke 7 yaitu 207 $\mathrm{mg} / \mathrm{dL}$ dan pada hari ke 14 yaitu 84,60 mg/dL. Berdasarkan hasil rata-rata kadar glukosa darah terjadi penurunan kadar glukosa darah pada hari 7 dan 14. Hal ini menunjukkan bahwa metformin merupakan obat antidiabetika golongan golongan biguanid dengan mekanisme kerja menurunkan produksi glukosa di hepar dan meningkatkan sensitivitas jaringan otot dan adipose terhadap insulin sehingga metformin merupakan obat yang efektif untuk mengobati diabetes pada mencit yang diinduksi dengan aloksan.

Pada kelompok F1 yang diberikan sediaan kapsul ekstrak etanol kulit pisang klutuk formula 1, diperoleh nilai rata-rata kadar glukosa darah pada hari ke 7 yaitu 218,40 mg/dL dan pada hari ke 14 yaitu 152,00 mg/dL. Pada kelompok F2 diberikan sediaan kapsul ekstrak etanol kulit pisang klutuk formula 2, diperoleh nilai rata-rata kadar glukosa darah pada hari ke 7 yaitu 177,20 $\mathrm{mg} / \mathrm{dL}$ dan pada hari ke 14 yaitu 106,80 mg/dL. Sedangkan pada kelompok F3 diberikan sediaan kapsul ekstrak etanol kulit pisang klutuk formula 3, diperoleh nilai rata-rata kadar glukosa darah pada hari ke 7 yaitu 166,80 mg/dL dan pada hari ke 14 yaitu 138,00 mg/dL. Hasil dari tiap kelompok yang diberi sediaan uji menunjukkan penurunan kadar glukosa darah.

Tabel 5. Rata-rata Kadar Glukosa Darah

\begin{tabular}{ccc}
\hline \multirow{2}{*}{ Kelompok } & \multicolumn{2}{c}{ Rata-rata Kadar Glukosa Darah $(\mathbf{m g} / \mathbf{d L}) \pm$ SD } \\
\cline { 2 - 3 } & Hari ke-7 & Hari ke-14 \\
\hline Kontrol Negatif & $508,60 \pm 84,39$ & $561,80 \pm 28,26$ \\
Kontrol Positif & $207,00 \pm 47,91$ & $84,60 \pm 16,16$ \\
F 1 & $218,40 \pm 80,08$ & $152,00 \pm 32,12$ \\
F 2 & $177,20 \pm 81,48$ & $106,80 \pm 21,23$ \\
F 3 & $166,80 \pm 16,45$ & $138,00 \pm 17,13$ \\
\hline
\end{tabular}

Selanjutnya dilakukan analisis data, diperoleh pada hari ke 7 dan ke 14 menunjukkan berdasarkan hasil analisis data uji normalitas bahwa nilai signifikan $>0,05$ yang berarti data Shapiro-Wilk, kadar glukosa darah yang berdistribusi normal. Berdasarkan hasil uji 
DOI : https://doi.org/10.24843/JFU.2020.v09.i03.p07

pISSN: 2301-7716; eISSN: 2622-4607

Jurnal Farmasi Udayana, Spesial Issue Desember 2020, 187-194

homogenitas Levene statistic nilai signifikan $>0,05$ yang berarti data bersifat homogen. Hasil uji one way ANOVA menghasilkan nilai signifikan $<0,05$ artinya data yang diperoleh menunjukkan terdapat perbedaan yang bermakna antar kelompok, maka dilakukan uji lanjutan yaitu uji LSD diperoleh nilai signifikan >0,05 pada kontrol positif dengan kelompok perlakuan
F2 yang menunjukkan tidak ada perbedaan bermakna.

Persentase penurunan kadar glukosa darah bertujuan untuk mengetahui penurunan kadar glukosa darah pada hari ke-7 dan ke 14 setelah pemberian sediaan uji dan juga untuk melihat efektivitas ekstrak etanol kulit pisang klutuk (Musa balbisiana Colla) sebagai antidiabetes.

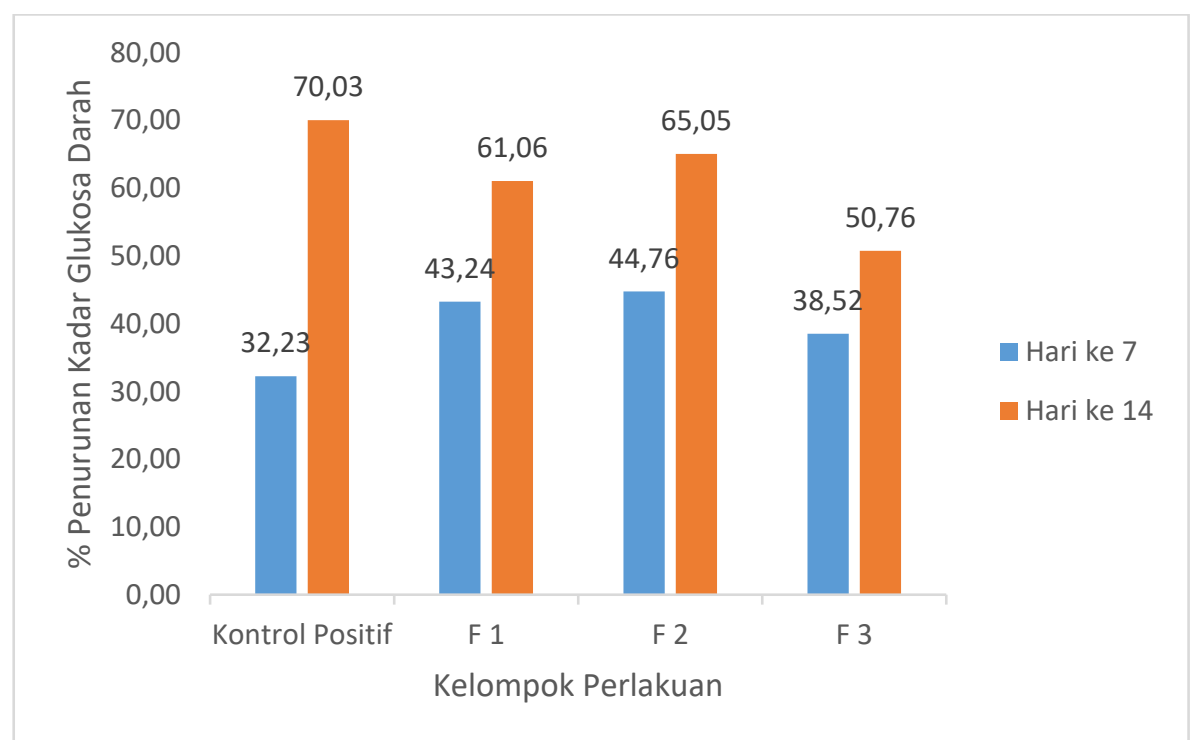

Gambar 1. Persentase Penurunan Kadar Glukosa Darah

\section{PEMBAHASAN}

Berdasarkan hasil penelitian, rata-rata persentase penurunan kadar glukosa darah yang diperoleh yaitu untuk kelompok kontrol negatif tidak terjadi penurunan kadar glukosa, untuk kelompok kontrol positif pada hari ke 7 yaitu $32,23 \%$ dan pada hari ke 14 yaitu 70,03\%, untuk kelompok formula 1 rata-rata persentase penurunan pada hari ke 7 yaitu 43,24\%, dan pada hari ke 14 yaitu $61,06 \%$. Kelompok dosis 2 ratarata persentase penurunan kadar glukosa darah pada hari ke 7 yaitu $44,76 \%$ dan hari ke 14 yaitu $65,05 \%$. Sedangkan untuk kelompok dosis 3 persentase penurunan kadar glukosa darah pada hari ke 7 yaitu 38,52\% dan pada hari ke 14 yaitu $50,76 \%$. Persentase penurunan sediaan uji yang paling tinggi ditunjukkan oleh kelompok formula 2. Hal tersebut dapat disebabkan karena pengaruh zat tambahan sodium starch glycolate yang digunakan. Proses terjadinya disintegrasi oleh sodium starch glycolate yaitu menyerap air lebih banyak tanpa membentuk gel yang dapat memperlambat disolusi (Mohanachandran, et al., 2011). Namun, sodium starch glycolate pada konsentrasi tinggi akan menimbulkan gelling sehingga kemampuan disintegrasi akan berkurang (Bala, et al., 2012).

\section{KESIMPULAN}

Berdasarkan penelitian yang telah dilakukan dapat disimpulkan bahwa sediaan kapsul ekstrak etanol kulit pisang klutuk (Musa 
DOI : https://doi.org/10.24843/JFU.2020.v09.i03.p07

pISSN: 2301-7716; eISSN: 2622-4607

Jurnal Farmasi Udayana, Spesial Issue Desember 2020, 187-194

balbisiana Colla) mempunyai aktivitas sebagai antidiabetes. Ekstrak etanol kulit pisang klutuk mengandung senyawa metabolit sekunder yang dapat berkhasiat sebagai antidiabetes diantaranya yaitu flavonoid, tanin, saponin dan polifenol. Hasil evaluasi sediaan menunjukkan ketiga formula memenuhi persyaratan. Dari ketiga formula sediaan kapsul ekstrak etanol kulit pisang klutuk yang digunakan, sediaan dengan formula 2 mempunyai aktivitas menurunkan kadar glukosa darah yang lebih baik daripada formula 1 dan 3 pada mencit jantan yang diinduksi aloksan.

\section{DAFTAR PUSTAKA}

1. Adnyana, Dewa Putu Anom., Meles, Dewa Ketut., Wurlina, Zakaria, Sunarni., Suwasanti, Niluh., (2016), Efek Anti Diabetes Buah Pare (Momordica charantia Linn.) Terhadap Kadar Glukosa Darah, Sel Penyusun Pulau Langerhans dan Sel Leydig pada Tikus Putih Hiperglikemia, Acta Veterinaria Indonesiana; 4(2) : 43-50.

2. Arifki, H. H., Barliana, M. I., Studi, P., Fakultas, S., Padjadjaran, U., \& Langit, T. (2018). Farmaka Farmaka. 16, 196-203.

3. Bala, Rajni, Sushil Khanna, Pravin Pawar. 2012. Polymers in Fast Disintegrating Tablets-A Review. Asian Journal of Pharmaceutical and Clinical Research 5(2): 814

4. Departemen Kesehatan Republik Indonesia. (1979). Farmakope Indonesia edisi III. Jakarta : Departemen Kesehatan Republik Indonesia

5. International Diabetes Federation. 2018. IDF DIABETES ATLAS. 8th Edition.

6. Ighodaro, Osasenaga M., Adeosun, Abiola M., Asejeje, Folake O., Soetan, Gabriel O., Kassim, Omolara O. (2018). Time course effects of 5,5-dihydroxyl pyrimidine-2,4,6trione (alloxan) as a diabetogenic agent in animal model. Alexandria Journal of Medicine. 54. pp. 705-710.
7. Jyothi, D., Koland, M., Priya, S., \& James, J. P. (2017). Formulation of Herbal Capsule Containing Trigonella Foenum-Graecum Seed Formulation of Herbal Capsule Containing Trigonella Foenum-Graecum Seed Extract for the Treatment of Diabetes. (September).

https://doi.org/10.5530/jyp.2017M Rusdi., Jumratul. J., Sitti. F. N., Hasyim. Bariun., 2017. Uji Efek Hipoglikemik Eksrak Etanol Batang Parang Romang (Boehmeria virgata (Forst) Guill) Terhadap Mencit (Mus Musculus) Jantan. JK FIK UINAM Vol.5 No.1 2017.

8. Liem, S., Yuliet, and Khumaidi, A. (2015) „Uji Aktivitas Antidiabetes Kombinasi Glibenklamid Dan Ekstrak Daun Salam (Syzygium polyanthum Wight.) Terhadap Mencit (Mus musculus) Yang Diinduksi Aloksan Antidiabetic Activity Test Of Combination Of Glibenclamide And Bay Leaf Extract (Syzygium polyanthum Wight.) To Alloxan Induced Mice (Mus musculus )ee, Journal of Pharmacy, 1 (1), pp. 42-47.

9. Mohanachandran., P. S., P.G. Sindhumol, T.S. Kiran. 2011. Superdisintegrant: An Overview. International Journal of Pharmaceutical Sciences Review and Research. Volume 6 Issue 1: 105- 109

10. Nurhayati. 2019. Uji Aktivitas Antidiabetes Ekstrak Etanol Kulit Pisang Klutuk (Musa balbisiana Colla) pada Tikus Putih Galur Wistar yang Diinduksi Aloksan (Skripsi). Tasikmalaya : STIKes Bakti Tunas Husada..

11. Priyatno D. 2012. Belajar Praktis Analisis Parametrik dan Non Parametrik dengan SPSS. Yogyakarta: Gava Media. 64-73 Rahma. 2014. Media Gizi Masyarakat Indonesia. Rumput laut sebagai bahan makanan kaya serat untuk obesitas padaremaja. Vol. 4. No. 1, April 2014, hlm. 1-8.

12. Purwati, Sri., Lumowa, Sonja V.T., Samsurianto. 2017. Skrining Fitokimia Daun Salaria (Lantana camara L) sebagai Pestisida Nabati Penekan Hama dan Insidensi Penyakit pada Tanaman Holtikultura di Kalimantan 
DOI : https://doi.org/10.24843/JFU.2020.v09.i03.p07

pISSN: 2301-7716; eISSN: 2622-4607

Jurnal Farmasi Udayana, Spesial Issue Desember 2020, 187-194

Timur. Prosiding Seminar Nasional Kimia 2017. Kimia FMIPA UNMUL.

13. Voight, R. (1989). Buku Pelajaran Teknologi Farmasi. Yogyakarta: Gadjah Mada University Press. 